\title{
Sodium Aluminosilicate Formation in Tank 43H Simulants
}

by

W. R. Wilmarth

Westinghouse Savannah River Company

Savannah River Site

Aiken, South Carolina 29808

D. D. Walker

S. D. Fink

This paper was prepared in connection with work done under the above contract number with the U.S. Department of Energy. By acceptance of this paper, the publisher and/or recipient acknowledges the U.S. Government's right to retain a nonexclusive, royalty-free license in and to any copyright covering this paper, along with the right to reproduce and to authorize others to reproduce all or part of the copyrighted paper.

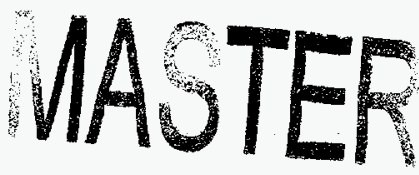

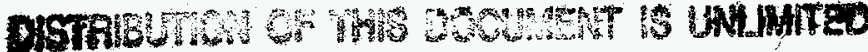

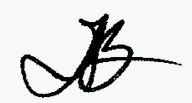




\section{DISCLAIMER}

This report was prepared as an account of work sponsored by an agency of the United States Government. Neither the United States Government nor any agency thereof, nor any of their employees, makes any warranty, express or implied, or assumes any legal liability or responsibility for the accuracy, completeness, or usefulness of any information, apparatus, product, or process disclosed, or represents that its use would not infringe privately owned rights. Reference herein to any specific commercial product, process, or service by trade name, trademark, manufacturer, or otherwise does not necessarily constitute or imply its endorsement, recommendation, or favoring by the United States Government or any agency thereof. The views and opinions of authors expressed herein do not necessarily state or reflect those of the United States Government or any agency thereof.

This report has been reproduced directly from the best available copy.

Available to DOE and DOE contractors from the Office of Scientific and Technical Information, P. O. Box 62, Oak Ridge, TN 37831; prices available from (423) 576-8401.

Available to the public from the National Technical Information Service, U. S. Department of Commerce, 5285 Port Royal Road, Springfield, VA 22161. 


\section{DISCLAIMER}

Portions of this document may be illegible electronic image products. Images are produced from the best available original document. 
WSRC-TR-97-00389, Rev. 0

Sodium Aluminosilicate Formation in Tank 43H Simulants (U)

W. R. Wilmarth

D. D. Walker

S. D. Fink

Publication Date: November 15, 1997

Westinghouse Savannah River Company

Savannah River Technology Center

Aiken, SC 29808

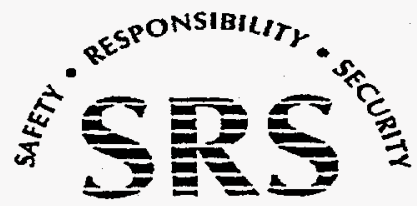

SAVANNAH RIVER SITE 


\section{DISCLAIMER}

This report was prepared by Westinghouse Savannah River Company (WSRC) for the United States Department of Energy under Contract No. DE-AC09-89SR18035 and is an account of work performed under that contract. Neither the United States Department of Energy, nor WSRC, nor any of their employees makes any warranty, expressed or implied, or assumes any legal liability or responsibility for the accuracy, completeness, or usefulness of any information, apparatus, or product or process disclosed herein or represents that its use will not infringe privately owned rights. Reference herein to any specific commercial product, process or service by trademark, name, manufacturer or otherwise does not necessarily constitute or imply endorsement, recommendation, or favoring of same by WSRC or the United States Government or any agency thereof. The views and opinions of the authors expressed herein do not necessarily state or reflect those of the United States Government or any agency thereof . 


\author{
Sodium Aluminosilicate Formation in Tank 43H Simulants (U) \\ W. R. Wilmarth, D. D. Walker and S. D. Fink \\ Waste Processing Technology Section \\ Savannah River Technology Center \\ Westinghouse Savannah River Company
}

\title{
Summary
}

This work studied the formation of a sodium aluminosilicate, $\mathrm{Na}_{8} \mathrm{Al}_{6} \mathrm{Si}_{6} \mathrm{O}_{24}\left(\mathrm{NO}_{3}\right)_{2} \bullet 4 \mathrm{H}_{2} \mathrm{O}$, at 40 ${ }^{\circ} \mathrm{C}, 95^{\circ} \mathrm{C}$, and $110^{\circ} \mathrm{C}$ in simulated waste solutions with varied amounts of silicon and aluminum. The data agree well with literature solubility data for sodalite, the analogous chloride salt. The following conclusions result from this work.

- The study shows, by calculation and experiments, that evaporation of the Septmeber 1997 Tank $43 \mathrm{H}$ inventory will only form minor quantities of the aluminosilicate.

-The data indicate that the rate of formation of the nitrate enclathrated sodalite solid at these temperatures falls within the residence time $(<4 \mathrm{~h})$ of liquid in the evaporator.

- The silicon in entrained Frit 200 transferred to the evaporator with the Tank43H salt solution will quantitatively convert to the sodium aluminosilicate. One kilogram of Frit 200 produces $2.1 \mathrm{~kg}$ of the sodium aluminosilicate

\section{Introduction}

During July of 1997 , operation of the $242-16 \mathrm{H}$ evaporator stopped due to low flow through the Gravity Drain Line (GDL) leading to Tank $38 \mathrm{H}$. The Gravity Drain Line includes a $250 \mathrm{ft}$ length of 304L stainless steel. Indications of flow restriction manifested as lower than expected lift rates of the concentrate from the evaporator. Video inspection of the Gravity Drain Line showed plugging of at least $90 \%$ of the inner diameter. Solid samples from the GDL showed a composition of $\mathrm{Na}_{8} \mathrm{Al}_{6} \mathrm{Si}_{6} \mathrm{O}_{24}\left(\mathrm{NO}_{3}\right)_{2} \bullet 4 \mathrm{H}_{2} \mathrm{O}$.'

Previously, Gasteiger et al. studied the equilibrium of silicon and aluminum in aqueous alkaline solutions containing chloride ion. ${ }^{2}$ The results of this work showed a dependency on several variables including temperature, hydroxide ion concentration and ionic strength. The dominant product formed during these studies was sodalite, $\mathrm{Na}_{8} \mathrm{Al}_{6} \mathrm{Si}_{6} \mathrm{O}_{24} \mathrm{Cl}_{2}$. One would expect that the nitrate enclathrated sodalite formed in the $242-16 \mathrm{H}$ Evaporator would exhibit similar solubility. 
After the initial discovery of solids, High Level Waste personnel expended significant manpower and expense in water blasting the GDL to remove the solid deposits. Concurrently, a research program started to determine the source of the soluble silicon and conditions for solid formation. The tests described in this report sought to determine if DWPF Frit 200 would dissolve in the aqueous alkaline waste, convert to the sodium aluminosilicate, and if the current inventory in Tank $43 \mathrm{H}$ would produce the nitrate enclathrated sodalite during either storage or during evaporation.

\section{Experimental}

\section{Initial Testing}

Provided in Results and Discussion section of this report.

\section{Frit Dissolution}

In these tests, Frit 200 was added to simulated salt solutions and heated at either 40 or $95^{\circ} \mathrm{C}$. The samples were prepared in steel bottles and mixed only prior to sampling. Three salt solutions were prepared: (1) simulated concentrate (11.5 M Na+, $8 \mathrm{M} \mathrm{NaOH}),(2)$ average salt solution (5 M Na+, $2 \mathrm{M} \mathrm{NaOH}$ ), and (3) DWPF recycle (0.7 M Na+, $0.5 \mathrm{M} \mathrm{NaOH}$ ). No aluminum was added to the salt solutions to prevent precipitation of the silicon. Frit 200 (2 wt $\%$ ) was added to each solution. Periodically, samples were taken, filtered, and analyzed for boron and silicon.

\section{Aluminosilicate Formation Testing}

Simulated Tank $43 \mathrm{H}$ salt solutions were prepared and spiked with varied amounts of silicon in the form of sodium silicate, $\mathrm{Na}_{2} \mathrm{SiO}_{3} \bullet 4 \mathrm{H}_{2} \mathrm{O}$. Silicon varied as a function of the aluminum concentration. The silicon/aluminum ratios studied included $1 / 100$, which is the current Tank $43 \mathrm{H}$ ratio, $1 / 10$, and $1 / 1$. Table 1 shows the composition of the stock salt solution.

The reaction vessels were carbon-steel, $160-\mathrm{mL}$ capacity containers. Solutions were added to the vessel and samples pulled periodically through a septum port using a 5-mL glass syringe. The reaction vessels were placed in pre-heated ovens at $40^{\circ} \mathrm{C}, 95^{\circ} \mathrm{C}$, and $110^{\circ} \mathrm{C}$. Temperatures were monitored using thermometers calibrated against standards traceable to NIST. 
Table 1. Simulated Tank $43 \mathrm{H}$ Solution

\begin{tabular}{cc} 
Component & Concentration (molar) \\
$\mathrm{Na}^{+}$ & 6.1 \\
$\mathrm{OH}^{-}$ & 4.0 \\
$\mathrm{NO}_{3}^{-}$ & 1.5 \\
$\mathrm{AlO}_{2}^{-}$ & 0.4 \\
\hline
\end{tabular}

Samples were filtered using a 0.2 micron syringe filter and submitted to the Analytical Development Section for analysis using Inductively Coupled Plasma - Emission Spectroscopy (ICP-ES). Researchers repeated the $95^{\circ} \mathrm{C}$ and $110^{\circ} \mathrm{C}$ testing due to erratic behavior of the silicon and aluminum concentrations in the 7.5 hour and 86 hour samples. Laboratory notebook WSRC-NB-97-62 contains data obtained during these tests along with the procedures used.

\section{$\underline{\text { Results and Discussion }}$}

The tests studied the rate of formation of the nitrate enclathrated sodalite at elevated temperatures similar to those found in the $242-16 \mathrm{H}$ evaporator. At these elevated temperatures, soluble silicon, in the form of $\mathrm{SiO}_{3}{ }^{2-}$, and aluminum in the form of $\mathrm{AlO}_{2}{ }^{2-}$, react to form a three dimensional structure with the formula $\left[\mathrm{Al}_{6} \mathrm{Si}_{6} \mathrm{O}_{24}\right]^{6}$. Figure 1 shows the cage-like structure of this anion. Previous work ${ }^{2}$ measured solubilities on the order of $10^{-4} \mathrm{~mol}^{2} / \mathrm{kg}$.

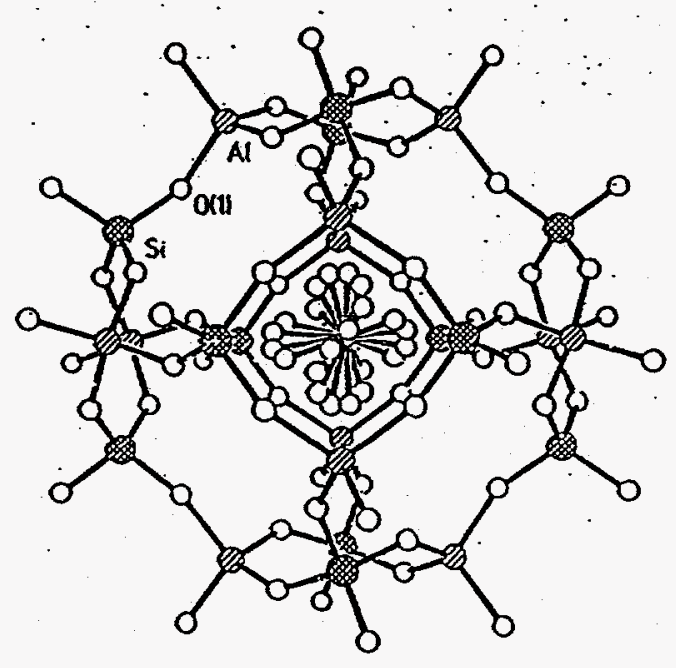

Figure 1. Structure of the Nitrate enclathrated Sodalite Anion. 
Initial Tests of Frit 200

Researchers performed two experiments to examine the formation of the aluminosilicate in simulated SRS waste. These experiments showed the nitrate salt of the aluminosilicate framework as the favored product, although another compound, presumably hydroxysodalite, forms when nitrate is minimized. The yield of product was near stoichiometric based on the amount of silicon added as Frit 200. This result agrees with the solubility data for sodalite shown in Figure 2. Frit 200 is currently used in the Defense Waste Processing Facility and some of it transferred to the tank farm. Table 2 lists the composition of the frit. For most tank farm waste solutions, aluminate exists in large excess over silicon. Thus, the introduction of silicon determines the amount of precipitate that forms.

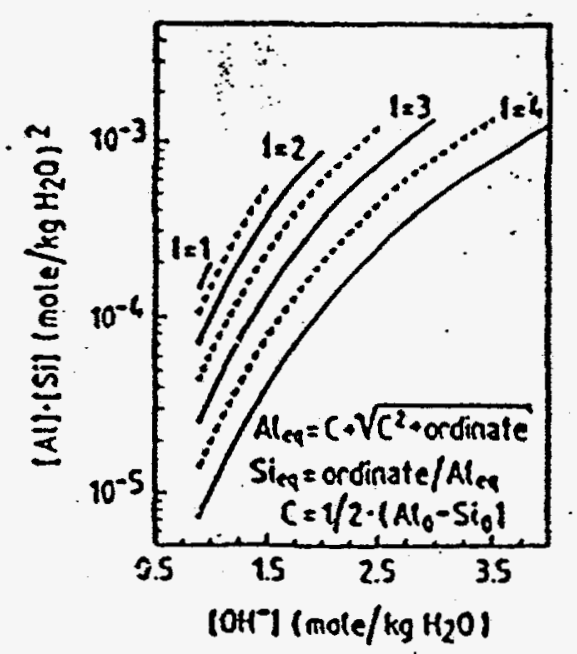

Figure 2. Solubility of Sodalite in Alkaline Solutions

Table 2. Composition of Frit 200

$\begin{array}{lc}\text { Component } & \text { Concentration (wt \%) } \\ \mathrm{SiO}_{2} & 70 \\ \mathrm{~B}_{2} \mathrm{O}_{3} & 12 \\ \mathrm{Na}_{2} \mathrm{O} & 11 \\ \mathrm{Li}_{2} \mathrm{O} & 5 \\ \mathrm{MgO} & 2\end{array}$


The first experiment used salt solution $(350 \mathrm{~mL})$ corresponding to the average waste composition shown in Table 1. Frit 200 (3.05 grams) was added and the solution boiled for two hours in a stainless steel beaker. During this time, solids were always present and the volume of solution was reduced by approximately $50 \%(175 \mathrm{~mL})$. The solution cooled overnight and copious amounts of salt crystallized. On the second day, water $(75 \mathrm{~mL})$ was added and the slurry was boiled again for 2.5 hours without reducing the volume. After cooling, the solids were filtered, washed with water, and dried for 2 hours at $85^{\circ} \mathrm{C}$. The yield of white powder was 4.63 grams. However, approximately 1-2 grams of compact solids adhered to the bottom, heated surface of the beaker and were discarded. The dried solids were identified as $\mathrm{Na}_{8}\left(\mathrm{Al}_{6} \mathrm{Si}_{6} \mathrm{O}_{24}\right)\left(\mathrm{NO}_{3}\right)_{2}-4 \mathrm{H}_{2} \mathrm{O}$ by X-ray diffraction (Figure 3). The yield measured $77 \%$ based on the silicon content of the Frit 200 . Allowing for discarding some material, the yield approached $100 \%$.

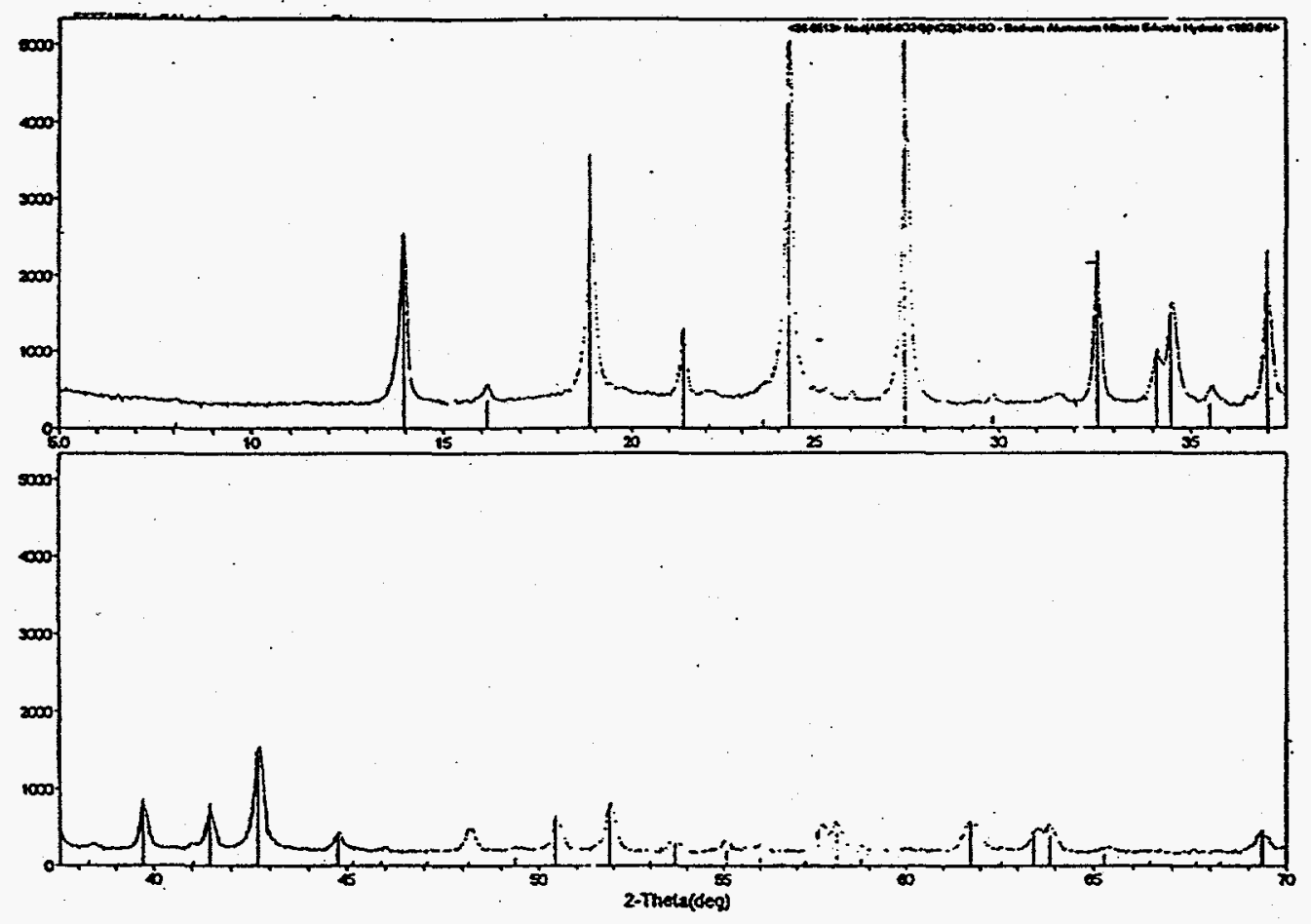

Figure 3. X-Ray Diffraction Pattern for Product of First Experiment (Reference spectrum of $\mathrm{Na} 8\left(\mathrm{Al}_{6} \mathrm{Si}_{6} \mathrm{O}_{24}\right)\left(\mathrm{NO}_{3}\right)_{2}-4 \mathrm{H}_{2} \mathrm{O}$ is also shown) 
The second experiment boiled Frit 200 (3.04 grams) in $3.0 \mathrm{M} \mathrm{NaOH}$ solution ( $350 \mathrm{~mL}$ ) for 2 hours in a stainless steel beaker. During this time, solids were always present and the volume of solution was reduced by approximately $50 \%(175 \mathrm{~mL})$. The solution cooled overnight with no significant change in the solids. On the second day, boiling was repeated for 2.5 hours without reducing the volume, during which time the frit dissolved leaving a slightly cloudy solution. After cooling, a solution $(100 \mathrm{~mL})$ of aluminum nitrate nonahydrate $(18.9 \mathrm{~g})$ and sodium hydroxide $(20.0$ grams) was added. No significant precipitation occurred over a three-day period at room temperature. The solution was boiled again for 3.5 hours and a precipitate formed. The solids were filtered, washed with water, and dried for 3.5 hours at $85^{\circ} \mathrm{C}$. The yield of white powder was 5.2 grams. Figure 4 shows the X-ray diffraction pattern for the product. The peak spacings appear very similar to the nitrate salt shown in Figure 3, but with different peak intensities. This product may include hydroxysodalite or a mixed hydroxide and nitrate compound. This result is not surprising since the concentration of nitrate ion in this experiment was very low compared to the first experiment. The yield of hydroxysodalite equals $93 \%$ of theoretical based on the silicon in the frit.

Table 3. Solubility Calculations for Simulant Experiments

\begin{tabular}{|c|c|c|}
\hline \multicolumn{3}{|c|}{ Experiment } \\
\hline & First & Second \\
\hline Component & \multicolumn{2}{|c|}{ Concentration (molar) } \\
\hline $\mathrm{Na}^{+}$ & 7.7 & 4.5 \\
\hline $\mathrm{Al}(\mathrm{OH})_{4}^{-}$ & 0.41 & 0.18 \\
\hline $\mathrm{Si}$ & 0.14 & 0.14 \\
\hline $\mathrm{OH}^{-}$ & 2.1 & 3.7 \\
\hline \multicolumn{3}{|l|}{$[\mathrm{Al}] \mathrm{x}[\mathrm{Si}], \mathrm{mol}^{2} / \mathrm{kg}^{2}$} \\
\hline experiment & $5.7 \times 10^{-2}$ & $2.5 \times 10^{-2}$ \\
\hline limit (Ref.2) & $1 \times 10^{-5}$ & $6 \times 10^{-4}$ \\
\hline Predicted yield: & $100 \%$ & $100 \%$ \\
\hline
\end{tabular}




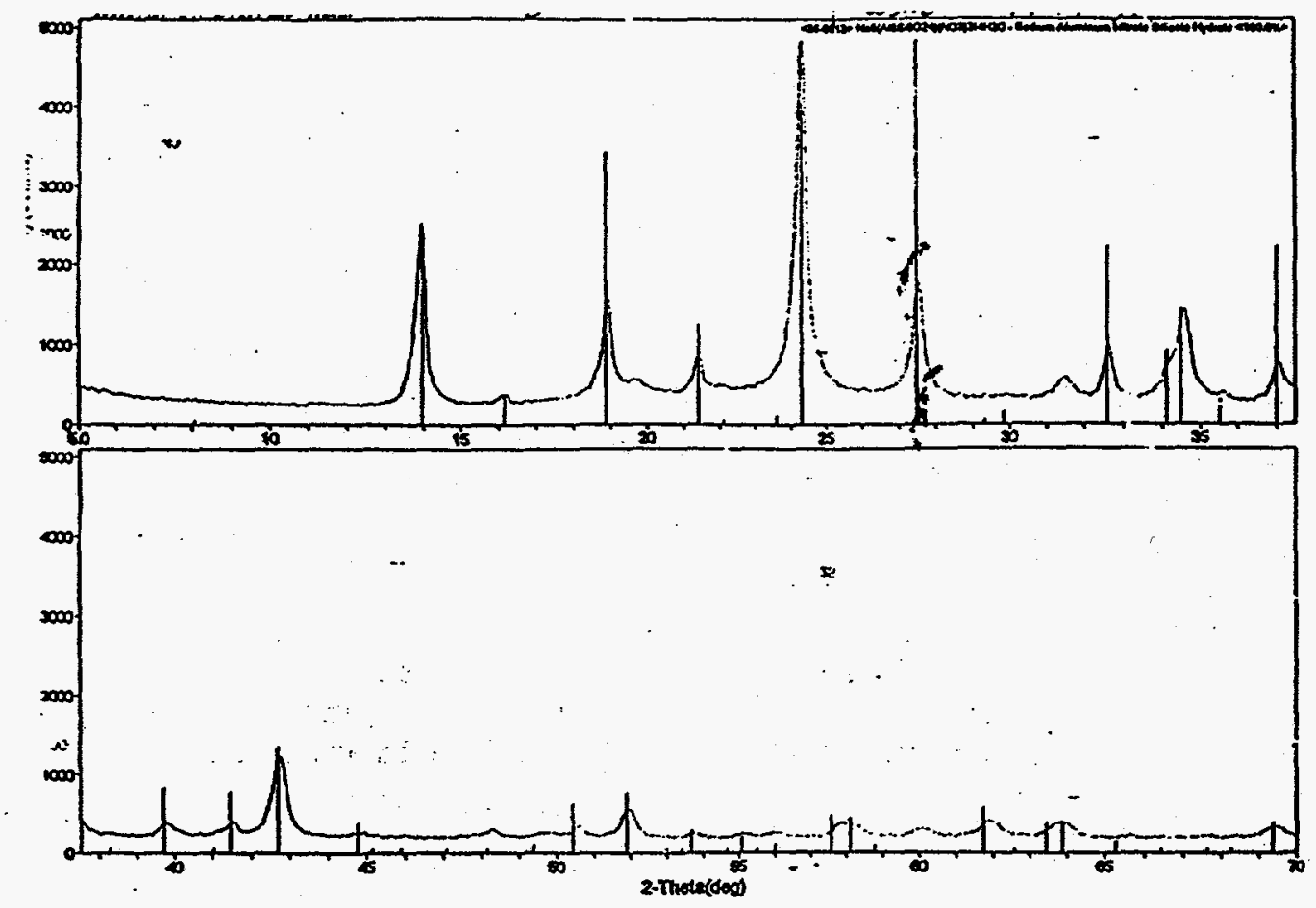

Figure 4. X-Ray Diffraction Pattern for Product of Second Experiment (Reference spectrum of $\mathrm{Na}\left(\mathrm{Al}_{6} \mathrm{Si}_{6} \mathrm{O}_{24}\right)\left(\mathrm{NO}_{3}\right)_{2}-4 \mathrm{H}_{2} \mathrm{O}$ is also shown)

Table 4. Expected Conditions for Tank 43H Salt Solution

Tank 43H salt solution composition

Component

$$
\mathrm{Na}^{+}
$$

$\mathrm{OH}^{-}$

$\mathrm{Al}(\mathrm{OH})^{-}$

$\mathrm{Si}$
Concentration (molar)

$6.2^{\mathrm{a}}$

$2.6^{\mathrm{b}}$

$0.13^{\mathrm{a}}$

$0.0015^{\mathrm{a}}$

Solubility product $[\mathrm{Al}] \mathrm{x}[\mathrm{Si}]\left(\mathrm{moles}^{2} / \mathrm{kg}^{2}\right.$ water)

$$
\begin{array}{ll}
\text { from Ref.1: } & 1 \times 10^{-4} \\
\text { observed: } & 2 \times 10^{-4}
\end{array}
$$

a Based on analyses of samples HTF-028 and HTF-029 by W. R. Wilmarth.

b Based on May 1997 sample reported in Reference 4. 
The high product yields in these two experiments indicate the aluminosilicate compound remains insoluble under the experimental conditions. This finding agrees with the solubility data for sodalite. Table 3 summarizes experimental conditions used in the tests reported here and the expected solubility derived from the sodalite data from Gasteiger, et al. ${ }^{2}$ For both experiments, the data in Figure 2 was extrapolated to estimate the limiting [Al]x[Si] product. The table ignores the effect of temperature with the solubility shown at $95^{\circ} \mathrm{C}$.

One can also use the sodalite data to predict the formation of the aluminosilicate compound when processing salt solution from Tank $43 \mathrm{H}$ through the evaporator. Table 4 lists the composition of Tank $43 \mathrm{H}$ salt solution and the expected solubility product.

The observed concentrations of aluminum and silicon agree closely with the solubility limit, indicating Tank $43 \mathrm{H}$ salt solution appears close to saturation relative to formation of the aluminosilicate compound. When processing the Tank $43 \mathrm{H}$ salt solution through an evaporator, the operation will precipitate not more than 1.5 grams of aluminosilicate per liter of Tank $43 \mathrm{H}$ feed. This amount of aluminosilicate is calculated based on silicon being the limiting reagent and complete conversion of the silicon to aluminosilicate. Under actual operating conditions, the yield will prove less.

Since the Tank $43 \mathrm{H}$ salt solution nears saturation, addition of silicon will precipitate the aluminosilicate compound. The reaction will occur almost quantitatively until the aluminum concentration drops appreciably. Thus, if Frit 200 transfers to the evaporator with salt solution, as much as 140 grams of aluminosilicate could form per liter of salt solution. This upper limit corresponds to $5 \mathrm{wt} \%$ frit in the salt solution and assumes all of the aluminum precipitates.

\section{Frit Dissolution Kinetics}

Frit dissolution tests indicate that frit dissolves rapidly in unstirred, hot salt solutions. Under well-mixed conditions in an evaporator, all of the frit in a $1 \mathrm{wt} \%$ feed will dissolve. At expected storage tank temperatures $\left(40^{\circ} \mathrm{C}\right)$, the rate decreases to less than $2 \%$ of the high temperature rate, but remains fast enough to dissolve significant amounts of frit during storage.

In these tests, Frit 200 was added to simulated salt solutions and heated at either 40 or $95^{\circ} \mathrm{C}$. The samples were prepared in steel bottles and mixed only prior to sampling. Three salt solutions were prepared: (1) simulated concentrate (11.5 M Na$+8 \mathrm{M} \mathrm{NaOH}),(2)$ average salt solution ( $\left.5 \mathrm{M} \mathrm{Na}^{+}, 2 \mathrm{M} \mathrm{NaOH}\right)$, and (3) DWPF recycle $\left(0.7 \mathrm{M} \mathrm{Na}^{+}, 0.5 \mathrm{M} \mathrm{NaOH}\right)$. Table 5 and 6 list the salt solution and Frit 200 compositions, respectively. No aluminum was added to the salt solutions so as to prevent precipitation of the silicon. Frit $200(2 \mathrm{wt} \%)$ was added to each solution. Table 6 lists the composition of Frit 200. Periodically, samples were taken, filtered, and analyzed for boron and silicon. Figures 5 and 6 show the changes in silicon and boron concentrations at $95^{\circ} \mathrm{C}$ and $40^{\circ} \mathrm{C}$ respectively. Table 7 lists the data graphed in the two figures. 
Table 5. Composition of Salt Solutions

\begin{tabular}{llcl} 
Component & \multicolumn{3}{c}{ Concentration (molar) } \\
& Concentrate & Average & DWPF Recycle \\
$\mathrm{Na}^{+}$ & 11.5 & 5.0 & 0.7 \\
$\mathrm{OH}^{-}$ & 8.0 & 2.5 & 0.5 \\
$\mathrm{NO}_{3}^{-}$ & 2.5 & 1.5 & 0.1 \\
$\mathrm{NO}_{2}^{-}$ & 0.5 & 0.5 & 0.1 \\
$\mathrm{SO}_{4}^{2-}$ & 0.25 & 0.25 & - \\
\hline
\end{tabular}

Table 6. Composition of Frit 200

$\begin{array}{cc}\text { Component } & \text { Concentration (wt \%) } \\ \mathrm{SiO}_{2} & 70 \\ \mathrm{~B}_{2} \mathrm{O}_{3} & 12 \\ \mathrm{Na}_{2} \mathrm{O} & 11 \\ \mathrm{Li}_{2} \mathrm{O} & 5 \\ \mathrm{MgO} & 2\end{array}$

At both temperatures, silicon concentrations in filtered samples increased linearly with time (Figures 5 and 6 ). At $95^{\circ} \mathrm{C}$, more than $70 \%$ of the frit dissolved in 24 hours. At $40^{\circ} \mathrm{C}$, only $20 \%$ of the frit dissolved in three weeks. Table 8 gives the rates of increase in silicon. Frit dissolution as measured by soluble silicon was confirmed by corresponding increases in soluble boron. The boron yields reached between 81 to $94 \%$ of the expected value calculated from the silicon results and frit composition. The low boron yields could reflect low boron content in this batch of frit, or biases in the analyses.

Only slight differences existed in rate between the three salt solution compositions at $95{ }^{\circ} \mathrm{C}$, but significant differences resulted at $40^{\circ} \mathrm{C}$. At both temperatures, the fastest rates occurred in average salt solution and the slowest rates in concentrate. This order of reactivity between the three solutions may reflect to opposing factors. Dissolution of silica should increase with higher sodium hydroxide concentrations. Thus, the concentrated solution should dissolve frit fastest of the three salt compositions. However, increased mixing should also increase the rate of dissolution. Under the test conditions with mechanical mixing only prior to sampling, the major 
mixing came from convection caused by temperature. Differences in viscosity may have significant impact on the convective mixing. Since the viscosity increases with hydroxide concentration, the concentrate should dissolve frit the slowest of the three. The balance between these opposing effects could produce the observed order of reactivity.

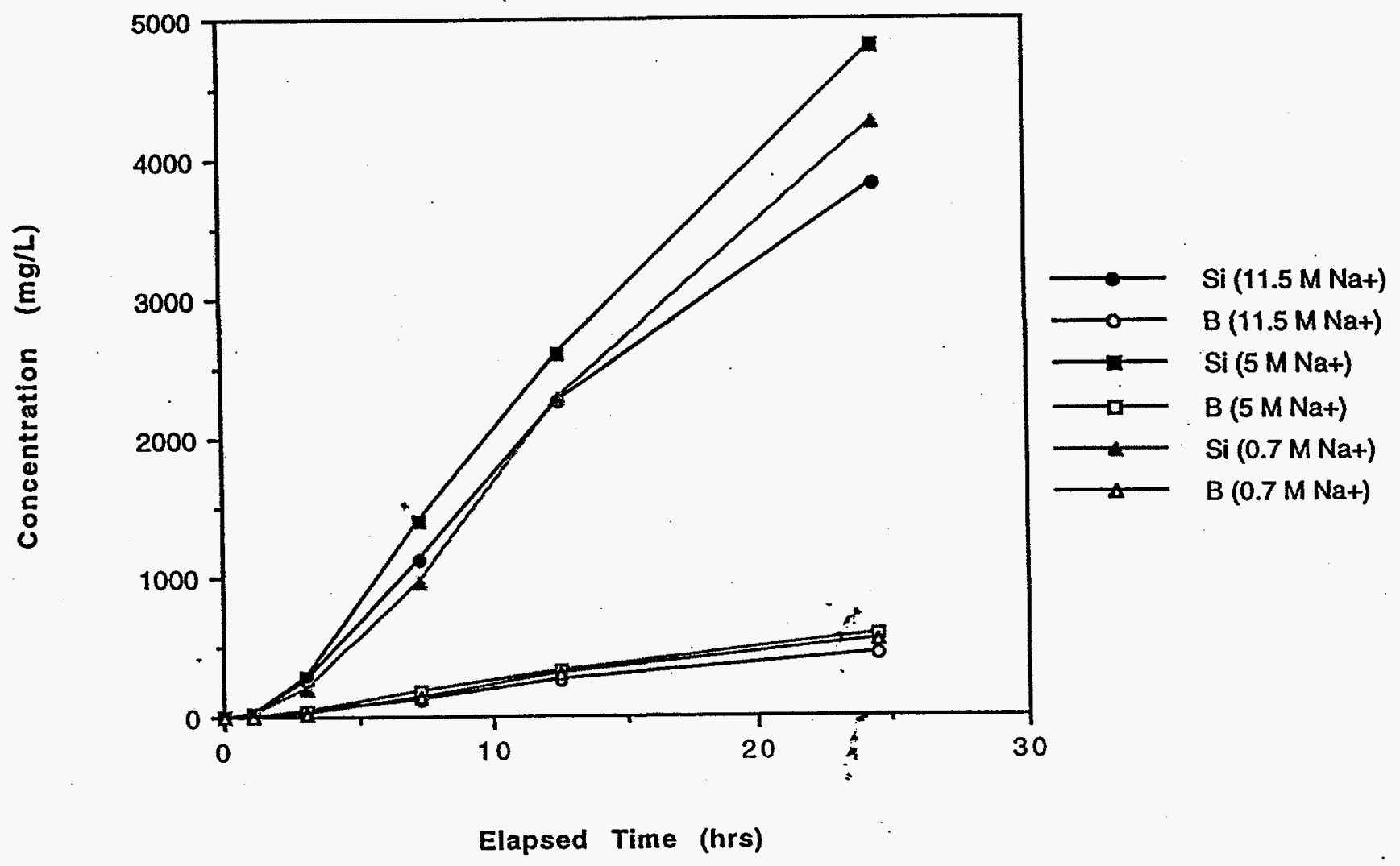

Figure 5. Silicon and Boron Behavior at $95^{\circ} \mathrm{C}$ 


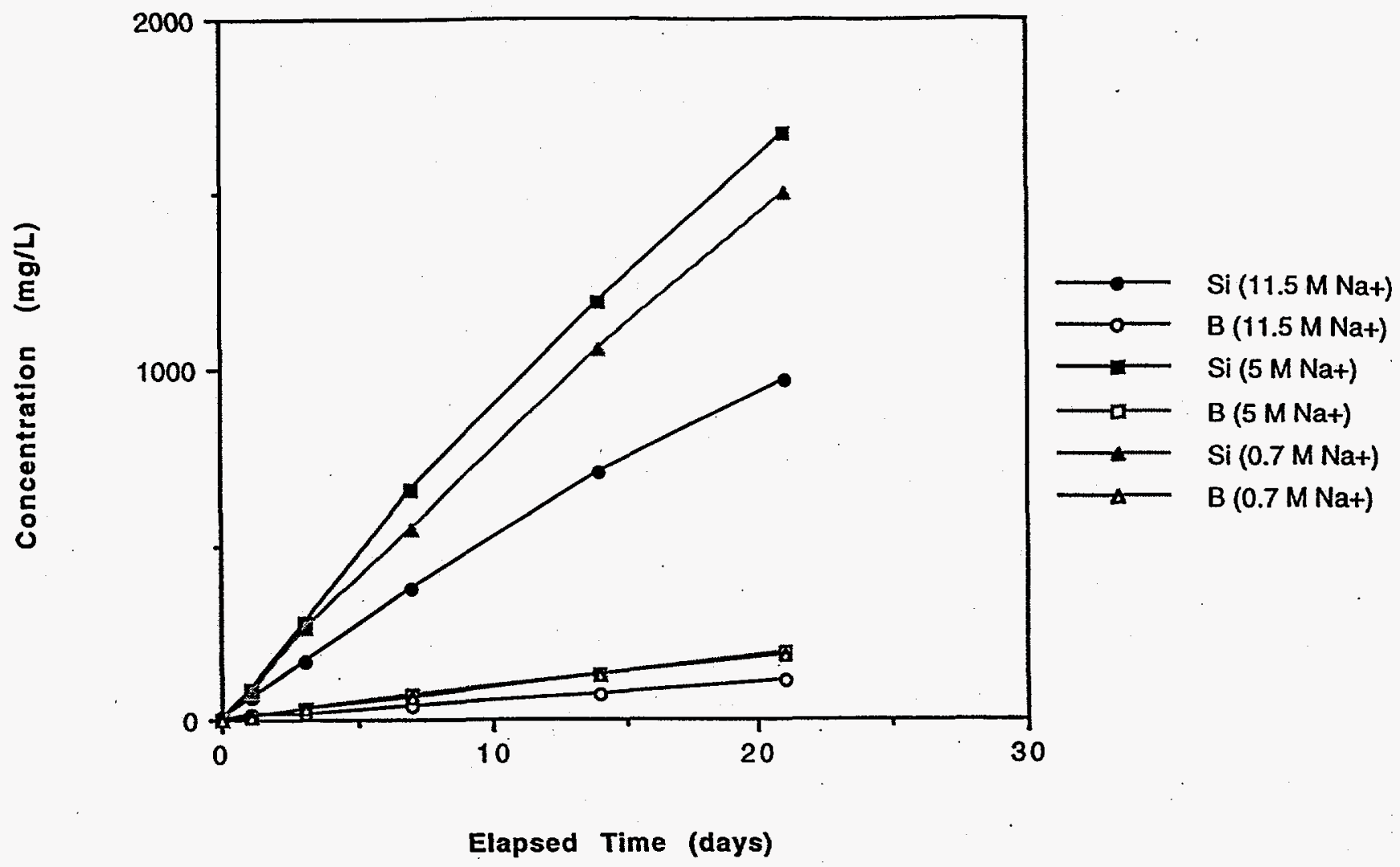

Figure 6. Silicon and Boron Behavior at $40^{\circ} \mathrm{C}$

\section{Sodium Aluminosilicate Formation Kinetics Testing}

In these experiments, soluble silicon and aluminum reacted quickly in aqueous alkaline solutions containing $3 \mathrm{M}$ hydroxide ion and $6 \mathrm{M}$ sodium ion. Table 9,10 , and 11 provide the data for the aluminum and silicon concentrations as a function of time for $40^{\circ} \mathrm{C}, 95^{\circ} \mathrm{C}$ and $110^{\circ} \mathrm{C}$, respectively.

\section{$\underline{40{ }^{\circ} \mathrm{C} \text { Tests }}$}

In conditions similar to the September 1997 inventory Tank 43H (i.e., 100/1 Al/Si for sample $\mathrm{Na} / \mathrm{Al} / \mathrm{Si}-26$ of Table 9), no loss of soluble silicon or aluminum occurred over a prolonged period $(72 \mathrm{~h})$ at $40^{\circ} \mathrm{C}$. However, this temperature was sufficient to affect a formation of the sodium aluminosilicate if excess silicon and aluminum exist in solution. Measurable loss of silicon occurred within 72 hours in sample $\mathrm{Na} / \mathrm{Al} / \mathrm{Si}-12$ with loss of aluminum observed in sample $\mathrm{Na} / \mathrm{Al} / \mathrm{Si}-24$. The calculated solubility product, $\mathrm{K}_{\mathrm{sp}}$, for the equilibrium silicon and aluminum concentrations ranged for $2.43 \times 10^{-4} \mathrm{~mol}^{2} / \mathrm{kg}^{2}$ to $8.7 \times 10^{-5} \mathrm{~mol}^{2} / \mathrm{kg}^{2}$. Formation of the aluminosilicate, even at this lower temperatures, occurs rapidly with an expected reaction half life of approximately 40 hours. 
W. R. Wilmarth, et al.

Table 7. Silicon and Boron Concentration in Salt Solutions

\begin{tabular}{lccc}
\hline Temperature $=95^{\circ} \mathrm{C}$ \\
Elapsed & \multicolumn{3}{c}{ Si Concentration $(\mathrm{mg} / \mathrm{L})$} \\
Time $(\mathrm{h})$ & Concentrate & Average & DWPF Recycle \\
0 & 8.1 & 1.9 & 0.6 \\
1 & 24. & 18. & 16. \\
3 & 258. & 290. & 193. \\
7.3 & 1124 & 1397 & 960 \\
12.5 & 2262 & 2609 & 2276 \\
24.5 & 3817 & 4798 & 4266 \\
\multicolumn{4}{c}{} \\
Elapsed & \multicolumn{4}{c}{} \\
Time (h) & Concentrate & Average & DWPF Recycle \\
0 & 1.7 & 0.01 & 0.01 \\
1 & 2.0 & 1.7 & 1.6 \\
3 & 31 & 36 & 26 \\
7.3 & 129 & 172 & 132 \\
12.5 & 262 & 321 & 292 \\
24.5 & 438 & 577 & 536
\end{tabular}

Temperature $=40^{\circ} \mathrm{C}$

Elapsed

Si Concentration $(\mathrm{mg} / \mathrm{L})$

Time (days) Concentrate Average DWPF Recycle

0

1

8.6

1.9

0.6

3

61

$89 \quad 76$

165.

$283 . \quad 266$

7

377

$657 \quad 542$

14

708

1190

1059

21

968

1672

1500

Elapsed

Time (days)

0

1

3

7

14

21

B Concentration (mg/L)

Concentrate Average DWPF Recycle

1.7

0.01

0.01

13

11

10

16

28

30

37

64

70

70

128

110

131

184 
W. R. Wilmarth, et al.

Table 8. Dissolution Rates

\begin{tabular}{llccc}
\hline & \multicolumn{5}{c}{ Rate } \\
& $95^{\circ} \mathrm{C}$ & $(\mathrm{mg} / \mathrm{L} / \mathrm{hr})$ & $4{ }^{\circ} \mathrm{C}(\mathrm{mg} / \mathrm{L} /$ day $)$ \\
Salt Solution & $\underline{\mathrm{Si}}$ & $\underline{\mathrm{B}}$ & $\underline{\mathrm{Si}}$ & $\underline{\mathrm{B}}$ \\
Concentrate & 164 & 19 & 46 & 5.0 \\
Average Salt & 204 & 25 & 80 & 9.1 \\
DWPF recycle & 182 & 23 & 72 & 8.8 \\
\hline
\end{tabular}

These observations, in conjunction with the dissolution rate of frit, indicate that the sodium aluminosilicate will form in Tank $43 \mathrm{H}$ prior to the evaporation process. Due to the specific gravity of the material, the sodium aluminosilicate will likely remain in the heel following transfer to the evaporator.

Table 9. Aluminum and Silicon Concentrations in Tank $43 \mathrm{H}$ Simulants at $40^{\circ} \mathrm{C}$

\begin{tabular}{lclllc}
\hline & & & & & \\
Sample & Time(h) & $\mathrm{Al}(\mathrm{mg} / \mathrm{L})$ & $\mathrm{Si}(\mathrm{mg} / \mathrm{L})$ & $\mathrm{Al}(\mathrm{mol} / \mathrm{L})$ & $\mathrm{Si}(\mathrm{mol} / \mathrm{L})$ \\
Na/Al/Si-26 & 1 & 2652 & 58.86 & 0.09830 & 0.00210 \\
1:100 Si:Al & 24 & 2649 & 53.86 & 0.09818 & 0.00191 \\
Ratio & 48 & 2511 & 54.4 & 0.09307 & 0.00192 \\
& 72 & 2658 & 46.41 & 0.09852 & 0.001652 \\
& & & & & \\
Na/Al/Si-12 & 1 & 2626 & 493.9 & 0.09733 & 0.01758 \\
1:10 Si:Al & 24 & 2636 & 482 & 0.09770 & 0.01716 \\
Ratio & 48 & 2540 & 346.0 & 0.09408 & 0.01232 \\
& 72 & 2298 & 80 & 0.08517 & 0.00285 \\
Na/Al/Si-24 & 1 & 161.1 & 1069 & 0.00598 & 0.03806 \\
1:1 Si:Al & 24 & 128.9 & 1033 & 0.00478 & 0.03678 \\
Ratio & 48 & 116.9 & 1202 & 0.00433 & 0.04279 \\
& 72 & 58.3 & 1127 & 0.00216 & 0.04012 \\
\hline
\end{tabular}

Note: Time "zero" samples were not taken. 
$95^{\circ} \mathrm{C}$ Tests

In conditions similar to evaporating the September 1997 inventory of Tank $43 \mathrm{H}$ (100/1 ratio of $\mathrm{Al} / \mathrm{Si}$ similar to samples $\mathrm{Na} / \mathrm{Al} / \mathrm{Si}-1$ and $\mathrm{Na} / \mathrm{Al} / \mathrm{Si}-10$ ), no loss of soluble silicon or aluminum occurred over a prolonged period at $95^{\circ} \mathrm{C}$. This finding agrees with estimates reported in the initial testing described above. The observed solubility product constant, $\mathrm{K}_{\text {sp }}$, measured 2.03 to $2.26 \times 10^{-4} \mathrm{~mol}^{2} / \mathrm{kg}^{2}$. Samples from the heated solutions remained clear. Subsequent filtering of the solution did not recover any measurable solids.

In tests containing silicon and aluminum above the solubility limit (i.e., tests $\mathrm{Na} / \mathrm{Al} / \mathrm{Si}-2,3,12$, 13 and 14), loss of silicon or aluminum occurred. The reaction occurred within the sampling time and produced solutions depleted in silicon for test number $\mathrm{Na} / \mathrm{Al} / \mathrm{Si}-2,12$ and 13 and depleted in aluminum for test number $\mathrm{Na} / \mathrm{Al} / \mathrm{Si}-3,14$, and 15 . The reaction completed within 5 to 6 hours. The observed $\mathrm{K}_{\mathrm{sp}}$ measured $2.42 \times 10^{-4} \mathrm{~mol}^{2} / \mathrm{kg}^{2}$ to $4.27 \times 10^{-5} \mathrm{~mol}^{2} / \mathrm{kg}^{2}$, with and average of $1.50 \times 10^{-4} \mathrm{~mol}^{2} / \mathrm{kg}^{2}$. In each case, $\mathrm{x}$-ray diffraction identified solids collected after filtration as the nitrate enclathrated sodium aluminosilicate.

\section{$110^{\circ} \mathrm{C}$ Tests}

As in the $95^{\circ} \mathrm{C}$ tests, the Tank $43 \mathrm{H}$ simulant $(\mathrm{Na} / \mathrm{Al} / \mathrm{Si}-4$ and $\mathrm{Na} / \mathrm{Al} / \mathrm{Si}-11)$ showed no reaction. The high aluminum and silicon values at 7.5 hours in the first run $(\mathrm{Na} / \mathrm{Al} / \mathrm{Si}-4)$ reflect a precipitation problem in the sample after sample collection. Analytical Development Section (ADS) personnel observed solids in the filtered sample. In general the 7.5-hour samples from each of the first tests showed abnormal results for all six tests. This sampling protocol apparently led to post-filtration precipitation, as observed by ADS personnel in at least one sample. However, the 86 hour sample showed similar solution values.

Reactions removing silicon and aluminum from solution occurred in the 10/1 (Na/Al/Si-5 and $\mathrm{Na} / \mathrm{Al} / \mathrm{Si}-13)$ and $1 / 1(\mathrm{Na} / \mathrm{Al} / \mathrm{Si}-6$ and $\mathrm{Na} / \mathrm{Al} / \mathrm{Si}-15)$ samples. The solubility products calculated from the data range from $1.4 \times 10^{-3} \mathrm{~mol}^{2} / \mathrm{kg}^{2}$ to $3.6 \times 10^{-5} \mathrm{~mol}^{2} / \mathrm{kg}^{2}$. These $\mathrm{K}_{\mathrm{sp}}$ values compare favorably to those obtained at $40^{\circ} \mathrm{C}$ and $95^{\circ} \mathrm{C}$ indicating little temperature dependence of solubility at the high ionic strength of these solutions. 
W. R. Wilmarth, et al.

WSRC-TR-97-00389

Page 17 of 21

Table 10. Aluminum and Silicon Concentrations in Tank $43 \mathrm{H}$ Simulants at $95^{\circ} \mathrm{C}$

\begin{tabular}{|c|c|c|c|c|c|}
\hline Sample & Time (h) & $\mathrm{Al}(\mathrm{mg} / \mathrm{L})$ & $\mathrm{Si}(\mathrm{mg} / \mathrm{L})$ & $\mathrm{Al}(\mathrm{mol} / \mathrm{L})$ & $\mathrm{Si}(\mathrm{mol} / \mathrm{L})$ \\
\hline \multirow[t]{6}{*}{$\mathrm{Na} / \mathrm{Al} / \mathrm{Si}-1$} & 0 & 2727 & 55.01 & 0.1011 & 0.00196 \\
\hline & 1 & 2765 & 60.69 & 0.1025 & 0.00216 \\
\hline & 3 & 2610 & 56.68 & 0.0967 & 0.00202 \\
\hline & 5 & 2741 & 59.61 & 0.1016 & 0.00212 \\
\hline & 7.5 & 2731 & 64.52 & 0.1012 & 0.00230 \\
\hline & 86 & 2638 & 64.82 & 0.0978 & 0.00231 \\
\hline \multirow[t]{6}{*}{$\mathrm{Na} / \mathrm{Al} / \mathrm{Si}-2$} & 0 & 2739 & 486.8 & 0.1012 & 0.01733 \\
\hline & 1 & 2633 & 453.6 & 0.0976 & 0.01615 \\
\hline & 3 & 2557 & 393.0 & 0.0948 & 0.01400 \\
\hline & 5 & 2667 & 377.9 & 0.0988 & 0.01345 \\
\hline & 7.5 & 2200 & 30.1 & 0.0815 & 0.00107 \\
\hline & 86 & 2159 & 32.8 & 0.0800 & 0.00117 \\
\hline \multirow[t]{6}{*}{$\mathrm{Na} / \mathrm{Al} / \mathrm{Si}-3$} & 0 & 2121 & 3225 & 0.0786 & 0.1148 \\
\hline & 1 & 915.4 & 1923 & 0.0339 & 0.0684 \\
\hline & 3 & 402.6 & 1336 & 0.0149 & 0.0476 \\
\hline & 5 & 268.8 & 1224 & 0.0100 & 0.0436 \\
\hline & 7.5 & 38.41 & 1016 & 0.0014 & 0.0362 \\
\hline & 86 & 29.79 & 1086 & 0.0011 & 0.0388 \\
\hline \multirow[t]{4}{*}{$\mathrm{Na} / \mathrm{Al} / \mathrm{Si}-10$} & 1 & 2772 & 57.77 & 0.1027 & 0.00206 \\
\hline & 3 & 2634 & 62.52 & 0.0976 & 0.00223 \\
\hline & 5 & 2685 & 62.43 & 0.0995 & 0.00222 \\
\hline & 32 & 2763 & 66.18 & 0.1024 & 0.00236 \\
\hline \multirow[t]{4}{*}{$\mathrm{Na} / \mathrm{Al} / \mathrm{Si}-12$} & 1 & 2626 & 493.6 & 0.0973 & 0.01758 \\
\hline & 3 & 2636 & 482 & 0.0977 & 0.01726 \\
\hline & 5 & 2540 & 346 & 0.0941 & 0.01232 \\
\hline & 32 & 2298 & 79.96 & 0.0852 & 0.00285 \\
\hline \multirow[t]{4}{*}{$\mathrm{Na} / \mathrm{Al} / \mathrm{Si}-14$} & 1 & 430.2 & 1520 & 0.0159 & 0.05411 \\
\hline & 3 & 346.3 & 1404 & 0.0128 & 0.05000 \\
\hline & 5 & 178.2 & 1242 & 0.0066 & 0.04422 \\
\hline & 32 & 38.67 & 1099 & 0.0014 & 0.03912 \\
\hline
\end{tabular}

Note: Time "zero" samples were not taken. 
Table 11. Aluminum and Silicon Concentrations in Tank $43 \mathrm{H}$ Simulants at $110^{\circ} \mathrm{C}$

\begin{tabular}{|c|c|c|c|c|c|}
\hline Sample & Time (h) & $\mathrm{Al}(\mathrm{mg} / \mathrm{L})$ & $\mathrm{Si}(\mathrm{mg} / \mathrm{L})$ & $\mathrm{Al}(\mathrm{mol} / \mathrm{L})$ & $\mathrm{Si}(\mathrm{mol} / \mathrm{L})$ \\
\hline \multirow[t]{6}{*}{$\mathrm{Na} / \mathrm{Al} / \mathrm{Si}-4$} & 0 & 2721 & 58.95 & 0.1004 & 0.00210 \\
\hline & 1 & 2707 & 58.57 & 0.1003 & 0.00209 \\
\hline & 3 & 2816 & 63.30 & 0.1044 & 0.00225 \\
\hline & 5 & 2983 & 64.90 & 0.1106 & 0.00231 \\
\hline & 7.5 & 7303 & 138.8 & 0.2707 & 0.00494 \\
\hline & 86 & 7526 & 144.8 & 0.2790 & 0.00515 \\
\hline \multirow[t]{6}{*}{$\mathrm{Na} / \mathrm{Al} / \mathrm{Si}-5$} & 0 & 2751 & 487.7 & 0.1020 & 0.01736 \\
\hline & 1 & 2214 & 303.0 & 0.0821 & 0.01078 \\
\hline & 3 & 2406 & 243.0 & 0.0892 & 0.00865 \\
\hline & 5 & 2438 & 203.6 & 0.0904 & 0.00725 \\
\hline & 7.5 & 2169 & 28.03 & 0.0804 & 0.00100 \\
\hline & 86 & 901.9 & 30.71 & 0.0334 & 0.00109 \\
\hline \multirow[t]{6}{*}{$\mathrm{Na} / \mathrm{Al} / \mathrm{Si}-6$} & 0 & 780 & 1828 & 0.0289 & 0.0651 \\
\hline & 1 & 97.38 & 1089 & 0.0036 & 0.0388 \\
\hline & 3 & 58.29 & 1113 & 0.0022 & 0.0396 \\
\hline & 5 & 50.22 & 1178 & 0.0019 & 0.0419 \\
\hline & 7.5 & 29.86 & 1662 & 0.0011 & 0.0592 \\
\hline & 86 & 30.66 & 1850 & 0.0011 & 0.0659 \\
\hline \multirow[t]{4}{*}{$\mathrm{Na} / \mathrm{A} / \mathrm{Si}-11$} & 1 & 2622 & 60.45 & 0.0972 & 0.00215 \\
\hline & 3 & 2689 & 68.68 & 0.0997 & 0.00225 \\
\hline & 5 & 2620 & 66.75 & 0.0971 & 0.00238 \\
\hline & 32 & 2638 & 58.34 & 0.0978 & 0.00208 \\
\hline \multirow[t]{4}{*}{$\mathrm{Na} / \mathrm{Al} / \mathrm{Si}-13$} & 1 & 2562 & 223 & 0.0946 & 0.00794 \\
\hline & 3 & 2454 & 166.5 & 0.0910 & 0.00593 \\
\hline & 5 & 2292 & 86.1 & 0.0850 & 0.00307 \\
\hline & 32 & 2208 & 44.83 & 0.0818 & 0.00160 \\
\hline \multirow[t]{4}{*}{$\mathrm{NA} / \mathrm{Al} / \mathrm{Si}-15$} & 1 & 361.1 & 1475 & 0.0134 & 0.05251 \\
\hline & 3 & 161.1 & 1195 & 0.0060 & 0.04254 \\
\hline & 5 & 72.08 & 1077 & 0.0027 & 0.03834 \\
\hline & 32 & 38.77 & 1064 & 0.0014 & 0.03788 \\
\hline
\end{tabular}

Note: Time "zero" samples were not taken. 


\section{$\underline{\text { Rate of Formation }}$}

These tests provide an estimate of the rate of formation of nitrate enclathrated sodalite in simulated evaporator. If one assumes the reaction proceeds first order in silicon, then the tests with an aluminum-to-silicon ratio of $10 / 1(\mathrm{Na} / \mathrm{Al} / \mathrm{Si}-2$ and $\mathrm{Na} / \mathrm{Al} / \mathrm{Si}-4)$ should provide kinetic information. The data for silicon concentration, neglecting the $7.5 \mathrm{~h}$ data points, was regressed using Microsoft $\otimes$ Excel to derive pseudo-first order rate constants. These rate constants measured $0.052 \mathrm{~h}^{-1}$ and $0.158 \mathrm{~h}^{-1}$ for $95^{\circ} \mathrm{C}$ and $110^{\circ} \mathrm{C}$, respectively. This data exhibits an activation energy for the formation of the sodalite solids of approximately $30 \pm 25 \mathrm{~kJ} / \mathrm{mol}$.

\section{Arrhenius Plot}

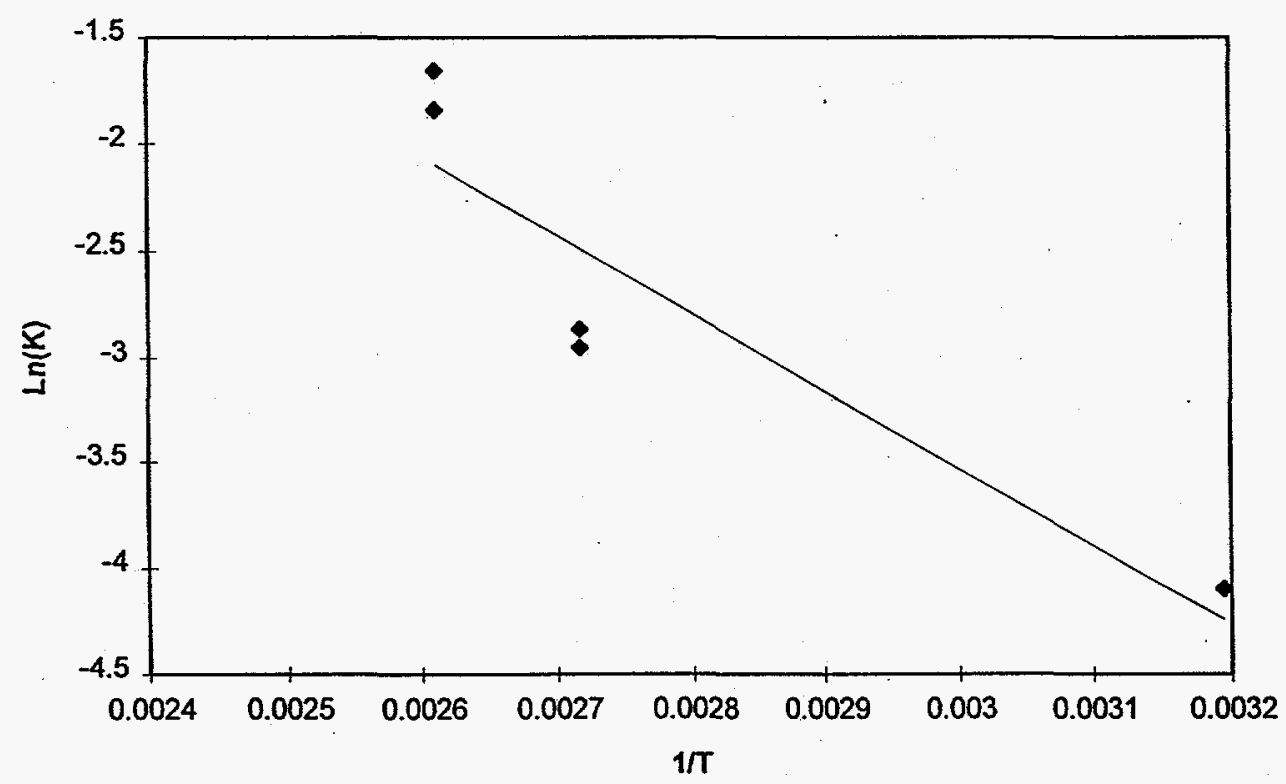

Figure 7. Arrhenius Plot of Sodium Aluminosilicate Formation 


\section{Conclusions}

Researchers studied the formation of the nitrated enclathrated sodium aluminosilicate. This insoluble compound formed in the $242-16 \mathrm{H}$ Evaporator and plugged the Gravity Drain Line feeding Tank $38 \mathrm{H}$. The results of this work indicate that Frit 200 used by the DWPF will dissolve rapidly in typical alkaline solutions at temperatures approximating the evaporator environment and will quantitatively convert to the sodium aluminosilicate. Formation, even at lower temperatures, occurs rapidly with an expected reaction half life at ambient temperatures of approximately 40 hours. Tests involving a Tank $43 \mathrm{H}$ simulant showed little or no solid formation. However, receipt of the DWPF Recycle stream in Tank $43 \mathrm{H}$ will introduce a source of silicon and renewed solid formation.

\section{Acknowledgments}

The authors wish to thank the dedicated support provided by the Analytical Development Section during the coarse of this work. Analyses were performed rapidly and with the highest quality. In particular, the authors wish to acknowledge Joe Clymire, David Missimer, and Laura Tovo.

\section{References}

1. W. R. Wilmarth, S. D. Fink, D. T. Hobbs and M. S. Hay, "Characterization and Dissolution Studies of Samples from the 242-16H Evaporator Gravity Drain Line," WSRC-TR-97-0326, Rev. 0, October 31, 1997.

2. H. A. Gasteiger, W. J. Frederick and R. C. Streisel, "Solubility of Aluminosilicates in Alkaline Solutions and a Thermodynamic Equilibrium Model," Ind. Eng. Chem. Res., 1992, $31,1183$.

3. J. C. Buhl and J. Lons, "Synthesis and Crystal Structure of Nitrate Enclathrated Sodalite $\mathrm{Na}_{8}\left[\mathrm{AlSiO}_{4}\right]_{6}\left(\mathrm{NO}_{3}\right)_{2}$, “J. Alloys and Compounds, 235 (1996), 41.

4. L. S. Livingston, "Tank Chemistry Report, May-June 1997 (U)," HLW-HLE-97-00136, July $16,1997$. 
W. R. Wilmarth, et al.

Approval:

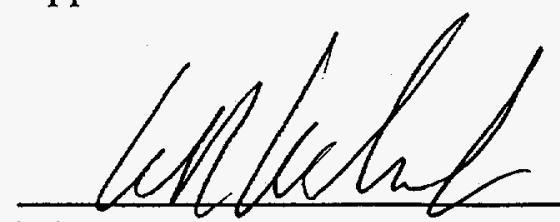

W. R. Wilmarth, Waste Processing Technology
WSRC-TR-97-00389

Page 21 of 21

11 March ig98

Date

Darrel W. Walker

$3 / 11 / 98$

D. D. Walker, Waste Processing Technology

Date

Samuel W2. In is

$3-15-98$

S. D. Fink, Manager

Date

Liquid Waste Processing

Gl em Toy for for BLLewis

$4 / 30 / 98$

Date CST Engineering 
CC: B. N. Attaway, 773-A

M. J. Barnes, 773-A

J. D. Carlson, 703-H

G. L. Cauthen, 241-119H

W. C. Clark, 704-56H

C. L. Crawford, 773-41 A

D. E. Doughty, 704-56H

R. E. Eibling, 704-T

S. D. Fink, 773-A

J. C. Griffin, 773-A

D. T. Hobbs, 773-A

R. A. Jacobs, 704-T

M. T. Keefer, 241-153H

L. F. Landon, 704-T

T. J. Lex, 703-H

D. J. McCabe, 773-43A

M. S. Miller, 704-56H

M. J. Montini, 704-56H

C. A. Nash, 773-42A

L. M. Papouchado, 773-A

S. F. Piccolo. 704-56H

M. J. Polochko, 773-A

P. L. Rutland, 241-152H

P. C. Suggs, 703-H

W. L. Tamosaitis, 773-A

W. B. Van Pelt, 676-1T

W. R. Wilmarth, 773-42A

TIM, 703-43A

WPTS Files, 773-A

ITP Files, c/o A. G. Wiest, 241-119H
J. L. Barnes, 704-S

N. E. Bibler, 773-A

J. T. Carter, 704-25S

M. C. Chandler, 703-H

P. F. Cloessner, 773-A

N. R. Davis, 703-H

L. O. Dworjanyn, 779-2A

H. H. Elder, 704-S

J. R. Fowler, 703-H

M. J. Hitchler, 992-3W

E. W. Holtzscheiter, 773-A

M. D. Johnson, 703-H

P. S. Kirkland, 703-46A

B. L. Lewis, 703-H

P. E. Lowe, 773-41A

J. W. McCollough, 703-H

T. M. Monahon, 703-H

J. P. Morin, 703-H

L. M. Nelson, 773-43A

R. A. Peterson, 773-A

M. R. Poirier, 676-T

C. T. Randall, 704-T

W. E. Stevens, 773-A

R. F. Swingle, 773-A

K. Thomas, 992-3W

D. D. Walker, 773-A

G. T. Wright, 773-A 